\title{
Indonesia - Vietnam Maritime Boundary: Problems and Prospects of Settlement
}

\author{
Jamal Hi Arsyad* \\ Faculty of Law, Khairun University, Indonesia
}

DOI: $10.36348 /$ sijlcj.2020.v03i10.003

| Received: 25.09.2020 | Accepted: 06.10.2020 | Published: 07.10.2020

*Corresponding author: Jamal Hi Arsyad

\section{Abstract}

There is no agreement regarding the maritime boundaries of the two countries, so that friction in the sea area often occurs, even if you look at the existing data for the period October 2014 to May 2019 there are 294 or about 57 percent of the ships destroyed by the Ministry of Maritime Affairs and Fisheries are violating vessels, the Vietnamese flag. The purpose of this paper is to analyze the development of negotiations on maritime boundaries between Indonesia and neighboring countries and the prospects for solving the maritime boundary problem between Indonesia and Vietnam. This type of research is normative using a statutory approach and a conceptual approach. The data used is secondary data obtained through library research. All data collected were then analyzed qualitatively. The results showed that the development of negotiations for maritime boundaries between Indonesia and neighboring countries began between Indonesia and Malaysia, followed by Indonesia-Singapore, Indonesia-Papua New Guinea, Indonesia-Australia, Indonesia-India, while the conflict in Natuna waters occurred because there was no agreement between Indonesia and Vietnam regarding the EEZ region of each country. Indonesia started discussing the EEZ boundary with Vietnam in 2010. From 2010 to 2016, negotiations on the determination of maritime boundaries between Indonesia and Vietnam have been held eight times. The two negotiators have agreed on several principles, the first is based on the International Convention on the Law of the Sea (UNCLOS 1982), although each country still requires technical, juridical and political considerations.

Keywords: Indonesia, maritime boundary, problems, prospects for settlement, Vietnam.

Copyright () 2020 The Author(s): This is an open-access article distributed under the terms of the Creative Commons Attribution license which permits unrestricted use, distribution, and reproduction in any medium for non-commercial use (NonCommercial, or CC-BY-NC) provided the original author and source are credited.

\section{INTRODUCTION}

Talking about maritime issues will never end; this is because countries have not finished making agreements regarding the maritime boundaries of their countries. Should these countries understand maritime boundary issues so that their main focus is on how to regulate maritime boundaries, be it their sovereign territory or areas where they have sovereign rights, so their main focus is before solving domestic problems? Is to settle state boundaries with neighboring countries so that there is no more friction regarding maritime boundaries in the future.

Sovereign rights are the powers that a state can have over certain areas which in its implementation must comply with the legal rules adhered to by the international community [1]. Claims on territory based on culture are often analogized to claims based on the doctrine of self-determination [2]. To determine the territorial boundaries of a country, several countries must determine their territorial boundaries not only on land but also in their marine areas. To determine state boundaries in mainland areas will certainly not be too difficult considering that each country will build a marker, post and place their state apparatus on guard at the border crossing posts of each country. This of course will be difficult if something similar is done in the ocean area, so determining state boundaries in the sea area only relies on an understanding made in the form of a document agreement between two or more countries, and then the document is ratified by each country so that it has legal force. When the document has been ratified by each country, each country can rely on their state apparatus (naval fleet) to patrol areas that have been mutually agreed upon.

The practice of ratification is important, so that each party can legally comply with the agreement that has been made together [3]. As a major subject in international law [4], the state must comply with international law, one of which is obeying the principle of the pacta sunt servanda. When this has been done 
(making an agreement document), and one or each of the parties violates the sea area, then of course the problem will be easily resolved because it will refer to a document that shows the maritime boundaries of each country, thus determining the parties who violate and being guilty of this incident would not be too difficult compared to the absence of an agreement document for the two countries. this is what is being experienced by Indonesia and Vietnam. There is no agreement on the maritime boundary between the two countries, so that friction in the sea area often occurs, even if you look at the existing data from October 2014 to May 2019, there are 294 or about 57 percent of the ships destroyed by the Ministry of Maritime Affairs and Fisheries are violating vessels, the Vietnamese flag.

Seeing this fact certainly raises many questions as to why Indonesia does not immediately finalize the agreement on its state boundaries, especially in the sea area with neighboring countries, even though as we all know that Indonesia is very aggressively diplomatic of its status as an archipelago in international forums. When Indonesia was supposed to gain legitimacy as an archipelagic country with the birth of the 1982 United Nations Convention on the Law of the Sea, the country's main focus was to fix maritime boundaries with neighboring countries as a form of gratitude for the status of an archipelago that has been recognized by the international community. If calculated until now, Indonesia has been running the wheels of government independently for 75 years, but along with the age of being independent for a long time, the problem of maritime boundaries with neighboring countries has not been resolved, even though Indonesia's maritime territory borders 10 countries. others, namely the Philippines, Palau, Papua New Guinea, India, Singapore, Australia, Timor Leste, Thailand, Malaysia and Vietnam. Based on this explanation, the problem that will be discussed in this paper is how is the development of negotiations on Indonesia's maritime boundaries with neighboring countries? and what are the prospects for solving the maritime boundary problem between Indonesia and Vietnam?

\section{RESEARCH METHOD}

This type of research is normative [5] by using a statutory approach and a conceptual approach [6]. The data used is secondary data obtained through library research [7]. All data collected were then analyzed qualitatively.

\section{RESULTS AND DISCUSSION \\ Indonesian Maritime Boundary Negotiations}

Indonesia has made diplomatic efforts to neighboring countries, be it diplomacy relating to the maritime boundaries of the two countries or diplomacy that is not related to maritime boundaries, such as the issue of civil servants, organized transnational crime, to the issue of international refugees. Indonesian diplomats have struggled as much as possible to defend the national interest and sovereignty of the country in front of other neighboring countries, but this diplomacy effort is not always successful in practice because there is also diplomacy that has been maximally attempted but ends up failing or deadlock because each country does not get common ground on issues that are diplomatic.

In general, diplomacy is management in relations between countries carried out by a country to achieve national interests as the implementation of its foreign policy. The concept of diplomacy has since expanded, both in terms of issues and actors, which in turn gave birth to various forms and types of diplomacy, one of which is maritime diplomacy. In simple terms, maritime diplomacy is the management of relations between countries through the maritime domain. According to Miere, maritime diplomacy does not only mean the use of diplomacy to manage conflicts and tensions between countries related to maritime issues through the preparation of international legal instruments. But maritime diplomacy is also the use of assets or resources in the maritime domain to regulate relations between countries. If diplomacy generally involves diplomats as representatives of the state, maritime diplomacy does not only involve policy makers (state actors). Maritime diplomacy can involve analysts and academics to study trends and developments in international relations and global security [8]. Diplomacy is needed by each country as the starting point for conflict resolution between the two. Many countries have their problems resolved only by diplomacy without having to cause tension or do it again until war starts.

Likewise, in the context of maritime diplomacy, the orientation target of Indonesia's maritime diplomacy is the Southeast Asia and ASEAN regions, before encouraging wider involvement on the global stage. This is inseparable from the various maritime problems experienced by Indonesia, many of which are in contact with neighboring countries in Southeast Asia, such as maritime boundary disputes, claims of maritime ownership, cases of illegal fishing, piracy, smuggling, the boundaries of the Exclusive Economic Zone (EEZ), and others. In addition, the affirmation of Indonesia's orientation to cooperate in the maritime sector with countries in the ASEAN region, both bilaterally and multilaterally, was expressed at the ASEAN Foreign Ministers' meeting on January 28, 2015 in Kinabalu [9]. Of course, the problem of illegal fishing that has been occurring between Vietnamese fishermen and Indonesian officials is not a trivial matter, plus this problem has not occurred once or twice, but more than two hundred times.

The first negotiations carried out by Indonesia were with Malaysia in November 1964. Using the equidistant line method (taking the same distance from 
each baseline as the boundary line), the two countries succeeded in agreeing on three segments of the continental shelf boundary. First, the segment in the Strait of Malacca along 400.8 nautical miles with an average equidistance distance of 18 nautical miles. Second, the segment in the South China Sea close to Malaysia, part of the peninsula along 317.2 nautical miles. Third, the segment in the South China Sea close to the island of Borneo along 260 nautical miles. However, the segment near the northwest of the Indonesian island of Tanjung Dato is not fully applicable because there is a concession agreement offered by Indonesia to Malaysia. This was done so that Malaysia would support Indonesia, which at that time was fighting for its claim to be an archipelago. Regarding territorial sea boundaries, the two countries only agreed on a segment in the southeastern part of the Straits of Malacca along 174 nautical miles in March 1970[10]. The concession agreement that was offered by Indonesia to Malaysia at that time which resulted in a reduction in the width of Indonesia's sea area was not really a problem, because at that time we did need the support of neighboring countries to gain legitimacy as an archipelagic state, but the problem was inconsistency. Governments from neighboring countries in disciplining their citizens, especially coastal patrol boats, have resulted in our marine area becoming an arena for illegal fishing.

The relevance of foreign policy to the character of a geographic country, or according to its historical background, which is also supported by the country's geopolitical and geostrategic perspective[11]. For the maritime boundary between Indonesia and Singapore, this area is a strategic international trade route. Therefore, the negotiations were also quite tough and long. At first, the two countries in May 1973 managed to agree on a territorial sea boundary in the Singapore Strait along 24.8 nautical miles using the equidistance method. This agreement still leaves two segments for the western and eastern segments, which are the extension of the agreed segment. After more than four decades, in March 2009 the two countries finally agreed on the western segment by drawing a median line between Nipah Island, Indonesia and Sultan Shoal Island, Singapore. As for the eastern segment, Singapore initially refused to discuss it because there was still a dispute with Malaysia regarding the ownership of Pedra Branca/Batu Puteh Island. With the issuance of the International Court of Justice's decision in May 2008 that the island belonged to Singapore, the prospect of negotiating the eastern segment was opened. However, these negotiations cannot now be carried out bilaterally, but must be trilateral by involving Malaysia. Meanwhile, the two countries do not have a continental shelf boundary [12]. The decisions of the International Court of Justice must be obeyed and implemented consistently by the state, as the main subject of international law and in providing an example of state compliance with other countries, the Indonesia-
Singapore-Malaysia trilateral negotiations must be attempted again.

The strengthening of the role of non-state actors, and the elimination of the concept of balance of power after the birth of the post-Westphalia Agreement [13]. On the maritime boundary between Indonesia and Papua New Guinea, the first negotiations were concluded in 1971 between Indonesia and Australia, which at that time represented Papua New Guinea. When Papua New Guinea became independent in 1975, the agreement remained in effect and divided the continental shelf boundaries of the two countries into two segments. The first segment is in the northern part of Papua Island in the Pacific Ocean. In 1980, the continental shelf boundary was extended northward to about 200 nautical miles using the equidistance method. The boundaries of the continental shelf are also the boundaries for the Exclusive Economic Zone (EEZ) and the fishing zone of the two countries. What is interesting about the 1980 agreement is the recognition of the traditional rights of citizens of both countries to fish in the waters of neighboring countries. The second segment is in the southern part of Papua Island in the Arafura Sea. Through the equidistance method, the two countries agreed on a 528 nautical mile boundary for the continental shelf [14]. The extension to the north to about 200 nautical miles using the equidistance method which is the boundary for the Exclusive Economic Zone (EEZ) and the fishing zone of the two countries is considered by many countries as the success of diplomacy between the two countries which led to a win-win solution, diplomacy and finally closing the potential for conflict for the two countries in the future.

Diplomacy is away taken to establish and maintain relationships and communicate with each other [15]. In the case of the Indonesia-Australia maritime boundary, since the 1970s, the two countries have agreed on two segments of the continental shelf boundary. First, the segment in the Arafura Sea along 530 nautical miles which was signed on 18 May 1971. Second, the segment in the Timor Sea which was agreed upon on 9 October 1972. However, this segment passed through the territory of East Timor which at that time was still a Portuguese colony, creating the Timor Gap. which intersects the continental shelf boundaries of the two countries. In the settlement process, the two countries used different approaches. Australia refers to the Geneva Convention 1958 with the principle of 200 $\mathrm{m}$ isobath or natural extension of the land, while Indonesia uses the principle of equidistance. These differences caused negotiations to fail to produce an agreement. In fact, the Timor Gap is an area rich in oil content; as a result the two countries competed for control of it. As an effort to reconcile the competition, on 5 September 1988 the two countries agreed to establish a zone of cooperation in carrying out oil licenses in the Timor Gap area. Along with the independence of East Timor, this cooperation was no 
longer valid. In March 1997, the two countries completed their agreement by agreeing on the EEZ boundary and the continental shelf between Christmas Island, Australia and Java Island, Indonesia, the EEZ boundary between the southern islands of Indonesia and Australia along 1,500 nautical miles, and an extension of the continental shelf boundary in 1972. December 2013, the agreement has not been ratified because the Indonesian side objected to the median line method used to determine the boundary between Java Island and Christmas Island[16]. The establishment of a zone of cooperation between Indonesia and Australia can be an inspiration when Indonesia will negotiate the boundaries of Indonesia's EEZ with Vietnam.

Lidya Sinaga (international political researcher from the Indonesian Institute of Sciences) said that the conflict in Natuna waters occurred because there was no agreement between Indonesia and Vietnam regarding the EEZ in those waters [17]. For the border between Indonesia and India, the two countries do not have territorial sea boundaries, but have boundaries of the continental shelf and EEZ. The continental shelf boundary is located around the Andaman Sea which separates Sumatra Island from the Nicobar Islands, known as the Great Channel. The delimitation agreement was first carried out on August 8, 1974 covering a 48 nautical mile segment using the equidistance method. On January 14, 1977, the segment was extended to the southwest by 160 nautical miles and to the northeast for 86 nautical miles. The end of this northeastward extension is close to the meeting point of the three countries' borders, namely Indonesia, India and Thailand, which are still being negotiated. Meanwhile, the EEZ boundary is still not resolved [18]. This unresolved diplomacy must immediately find a solution because in addition to this problem, the escalation of China's entry into the South China Sea conflict will drag on, making the problems between countries in the Region even more complicated.

Maritime boundary diplomacy with Malaysia and Vietnam to establish EEZ boundaries with Indonesia is also an important strategy that must be prioritized by the government to strengthen Indonesia's EEZ position and claims in the waters of the Natuna Islands. At the domestic level, the government's efforts to eradicate IUU fishing are carried out through the implementation of a policy of burning and sinking ships, holding a moratorium, prohibiting the use of dangerous fishing gear, and developing fishery infrastructure in Natuna [19]. On the maritime border between Indonesia and Thailand, the two countries border the continental shelf in the Malacca Strait. The first delimitation agreement was signed on 17 December 1971 on a bilateral basis. The 89 nautical mile segment is agreed on the principle of equidistance. In addition, there are two maritime boundaries that must be resolved trilaterally. First, the Indonesia-IndiaThailand border as described in the previous paragraph.
Second, the Indonesia-Thailand-Malaysia border which was agreed on December 21, 1971. The three countries agreed to establish a Common Point in the northern sector of the Malacca Strait as a meeting point for their continental shelf. The method used is more on (political) negotiation, not equidistance. Therefore, the distance between the Common Point and the starting point varies from country to country. The closest distance is Indonesia, which is 52 nautical miles from Sumatra, followed by Thailand with 76 nautical miles from Kho Butang, and the farthest, namely Malaysia with 99 nautical miles from Langkawi. Common Point is important in the midst of Indonesia's efforts in determining the outer boundaries of its maritime territory, even though the distance between the Common Point and the starting point of each country varies, at least the agreement can be considered successful if each country can be consistent in protecting its territory. Each of them so that illegal fishing does not occur.

\section{Prospects for Resolving Issues on Indonesian- Vietnam Maritime Boundaries}

In 2015, Indonesia succeeded in encouraging the formation of two forums. First, the RI-Malaysia forum on the Technical Meeting on Maritime Delimitation. The results of the RI-Malaysia forum agreed on the need to appoint a special envoy to accelerate the resolution of border problems, both maritime and land boundaries with Malaysia, given the complex border issues between the two countries. Second, the Indonesia-Vietnam forum regarding the determination of EEZ boundaries. In the various technical meetings that have been held, the results indicate a change in Vietnam's attitude to make the completion of EEZ boundary determination a priority in the framework of Vietnam's strategic partnership. In addition, Vietnam also agreed to make the 1982 UNCLOS maritime law convention the legal basis for the withdrawal and determination of the EEZ boundary [20]. In the future, the results of the negotiations and agreements with Vietnam will provide clarity for Indonesia regarding the boundaries of sovereign rights for the management of marine resources, particularly fisheries [21]. Vietnam's change in attitude to make the completion of EEZ boundary determination a priority in the framework of Vietnam's strategic partnership must be immediately followed up and maximized by Indonesia so that the EEZ issue can meet an agreement, so that this will indirectly facilitate ASEAN countries in dealing with China's unilateral claims. In the South China Sea.

Indonesia as a sovereign country has succeeded in implementing Maritime Diplomacy since the Djuanda Declaration in 1957 with the results of the Archipelagic State Concept and the birth of new legal norms, namely the width of the territorial sea of 12 nautical miles measured by drawing a straight line from the outermost point. The new legal norms were also 
accepted at UNCLOS 1982 after 25 years of diplomacy and negotiations. Thus, the inclusion of Maritime Diplomacy as part of Indonesia's Maritime Policy during the administration of President Joko Widodo is appropriate because Maritime Diplomacy is a mechanism for achieving the World Maritime Axis and making Indonesia an archipelagic country sovereign over its territory [22]. Seeing these developments, Najamuddin Khairur Rijal put forward three forms of maritime diplomacy as put forward by Christian Le Miere as follows: [23]

First, cooperative methods carried out through diplomacy to encourage bilateral cooperation with Malaysia, Vietnam and the Philippines as well as trilaterally between Indonesia-Malaysia-Philippines. With the aim of resolving maritime boundary and EEZ overlapping issues which are realized through technical meetings and collaborative meetings with Malaysia and Vietnam; establishing sea connectivity through a joint declaration with the Philippines; and facing maritime security threats together with the agenda of joint patrols in the territorial waters of Indonesia-Malaysia-the Philippines. The bilateral cooperation between Indonesia and Vietnam is one of the prospects for solving the maritime boundary issue of the two countries in the future.

Second, maritime diplomacy in a persuasive form is carried out to obtain and increase the recognition of other countries of Indonesia's maritime sovereignty. His efforts are realized by initiating maritime cooperation at the regional level through EAS and ARF. In addition, the proposal that IUU fishing is included as a transnational crime, the need for a mechanism or legal instrument to eradicate IUU fishing and the agreement on IUU fishing shows that Indonesia is trying to persuade. Its mouth is closely related to Indonesia's interests as an archipelagic country facing various maritime security threats. At the same time, it can be seen as Indonesia's effort to affirm its maritime sovereignty, territorial integrity, national identity, and state authority in the international system. IUU Fishing is indeed very detrimental to Indonesia, according to the CEO of the Indonesian Justice Initiative, Mas Achmad Santosa, at least Indonesia has suffered losses of up to USD 4 billion per year or equivalent to IDR 56.13 trillion. Even the former Minister of Maritime Affairs and Fisheries, Susi Pudjiastuti, said that Indonesia's losses due to illegal fishing have reached IDR 2,000 trillion. Reflecting on these losses, and seeing the reality in the field that about 57 percent of the ships destroyed by the Ministry of Maritime Affairs and Fisheries are violators with Vietnamese flags, Indonesia must immediately resolve the issue of maritime boundaries with Vietnam.

Third, the coercive policy through prosecution of foreign ships that commit violations in Indonesia's maritime territory shows that in addition to soft means,
Indonesia is also capable of taking firm and tough actions. This coercive form also shows that maritime sovereignty is essential for Indonesia and therefore the government mobilizes a component of maritime power as evidence of the state's existence in its maritime sovereignty area. The prosecution of foreign vessels committing violations in Indonesia's maritime territory must be carried out, as well as the destruction of Vietnamese-flagged vessels in order to maintain the image and dignity of the Indonesian people as a strong country, and an embarrassing incident, namely the case of two government surveillance vessels. Vietnam which crashed into the hull of the Indonesian Navy ship KRI Tjiptadi-381 in the North Natuna Sea did not happen again.

Based on the research results uploaded on the official website of the National Seminar on the Geospatial Information Agency, Indonesia began discussing the EEZ boundary with Vietnam in 2010. From 2010 to 2016, negotiations on the determination of maritime boundaries between Indonesia and Vietnam have been held eight times. Director-General of Law and International Treaties Damos Dumoli Agusman said the EEZ boundary negotiations are still ongoing at the technical level. The two negotiators, said Damos, had agreed on several principles, the first was based on the International Law of the Sea Convention (UNCLOS 1982). Indonesia and Vietnam, he said, also emphasized the principle that the continental shelf boundary and the EEZ are two different regimes. According to the International Law of the Sea Convention, the continental shelf includes the rights of a country to the seabed and the land beneath which lies outside the territorial sea. "Then the two negotiators began to negotiate the line (EEZ) were and this requires technical, juridical and political considerations," said Damos. He added that maritime boundary negotiations do take a long time. "Previously, the negotiations on the continental shelf boundary with Vietnam lasted for more than 30 years, since 1973 and only finished in 2003," he concluded. LIPI observer Lidya Sinaga said that as ASEAN countries, Indonesia and Vietnam must resolve maritime boundary issues because this is important for regional stability. He added that the Indonesian government also needs to strengthen its maritime diplomacy commitment in this regard [24]. Of course, once again the author emphasizes here that the completion of the EEZ region agreement between Indonesia and Vietnam can indirectly facilitate ASEAN countries, especially the two countries in dealing with China's unilateral claims in the South China Sea.

\section{CONCLUSION}

The development of negotiations on maritime boundaries between Indonesia and neighboring countries began in November 1964, namely negotiations between Indonesia and Malaysia, then followed by Indonesia-Singapore in May 1973, then the maritime boundary between Indonesia and Papua New 
Guinea, the first negotiations were agreed upon in 1971 between Indonesia and Australia, which at that time represented Papua New Guinea. When Papua New Guinea became independent in 1975, the treaty remained in effect. Furthermore, the IndonesiaAustralia maritime boundary, the two countries since the 1970s have agreed on two segments of the continental shelf boundary. The border between Indonesia and India, the two countries do not have territorial sea borders, but have boundaries of the continental shelf and EEZ. The delimitation agreement was first carried out on August 8, 1974. Meanwhile, the conflict in Natuna waters occurred because there was no agreement between Indonesia and Vietnam regarding the EEZ area of each country.

Indonesia started discussing the EEZ boundary with Vietnam in 2010. From 2010 to 2016, negotiations on the determination of maritime boundaries between Indonesia and Vietnam have been held eight times. The two negotiators have agreed on several principles, the first is based on the International Law of the Sea Convention (UNCLOS 1982). Indonesia and Vietnam also emphasized the principle that the continental shelf boundary and the EEZ are two different regimes. Furthermore, the two negotiators began to negotiate the EEZ lines of each country so that it still requires technical, juridical and political considerations.

\section{REFERENCES}

1. Parthiana, I. W. (2014). Hukum Laut Internasional dan Hukum Laut Indonesia. Yrama Widya.

2. Cassese, A. (1995). Self-determination of peoples: a legal reappraisal (No. 12). Cambridge University Press.

3. Latif, B., \& Kadarudin. (2013). Hukum perjanjian internasional. Pustaka Pena Press Makassar.

4. Birkah Latif and Kadarudin. (2013). Pengantar Hukum Internasional, (Makassar: Pustaka Pena Press, 2013), p. 72 See also Kadarudin, Antologi Hukum Internasional Kontemporer, (Yogyakarta: Deepublish, 2020), 492

5. Soerjono Soekanto and Sri Mamudji. (2011). Penelitian Hukum Normatif, (Jakarta: Rajawali Pers, 2011), p. 14

6. Peter, M. M. (2010). Penelitian Hukum, (Jakarta: Kencana Prenada Media Group, 2010), 96

7. Kadarudin. (2020). Mengenal Riset dalam Bidang Ilmu Hukum: Tipologi, Metodologi, dan Kerangka, (Ponorogo: Uwais Inspirasi Indonesia, 2020), 171
8. Christian, L. M. (2014). Maritime Diplomacy in the 21 st Century: Drivers and Challenges, (New York: Routledge, 2014) in Najamuddin Khairur Rijal, Smart Maritime Diplomacy: Diplomasi Maritim Indonesia Menuju Poros Maritim Dunia, Global \& Strategis, Th. 13(1), 68

9. Yuni Arisandy. "Indonesia Dorong Kerja Sama Maritim Di ASEAN", See https://www.antaranews.com/berita/476879/indone sia-dorong-kerja-sama-maritim-di-asean. In Najamuddin Khairur Rijal, Ibid.

10. Raharjo, S. N. I. (2016). Menegosiasikan Batas Wilayah Maritim Indonesia Dalam Bingkai Negara Kepulauan. Masyarakat Indonesia, 41(2), 227-232.

11. Supriyatno, M. (2014). Tentang ilmu pertahanan. Yayasan Pustaka Obor Indonesia.

12. Sandy Nur Ikfal Raharjo. (2015). Loc.Cit.

13. Hilz, W. (2007). Hans J. Morgenthau, Politics Among Nations: The Struggle for Power and Peace, New York 1948. In Schlüsselwerke der Politikwissenschaft (pp. 310-314). VS Verlag für Sozialwissenschaften.

14. Raharjo, S. N. I. (2015). Peran identitas agama dalam konflik di Rakhine Myanmar tahun 2012 2013. Jurnal Kajian Wilayah, 6(1), 35-59.

15. Brownlie, I. (1980). Principles of public international law. VRÜ Verfassung und Recht in Übersee, 14(1), 92-93.

16. Raharjo, S. N. I. (2015). Peran identitas agama dalam konflik di Rakhine Myanmar tahun 20122013. Jurnal Kajian Wilayah, 6(1), 35-59.

17. Wijaya, C. (2019). Konflik IndonesiaVietnam'terancam terus berulang'selama belum ada kesepakatan Zona Ekonomi Ekslusif.

18. Sandy Nur Ikfal Raharjo. (2015), Loc.Cit., 232

19. Riska, E. (2017). Diplomasi Maritim Indonesia Terhadap Aktivitas Penangkapan Ikan Ilegal (Illegal Fishing) oleh Nelayan China di ZEE Perairan Kepulauan Natuna. Diplomasi Pertahanan, 3(2).

20. Direktorat Jenderal Asia Pasifik dan Afrika. (2016). Laporan Kinerja Direktorat Jenderal Asia Pasifik dan Afrika 2015, (Jakarta: Kementerian Luar Negeri RI, 2016).

21. Najamuddin Khairur Rijal, Loc.Cit., 70

22. Indriati Kusumawardhani dan Arie Afriansyah. (2019). Kebijakan Kelautan Indonesia dan Diplomasi Maritim, Kertha Patrika, 41(3), 254-255

23. Najamuddin Khairur Rijal, Loc.Cit., 73

24. Callistasia, W. (2019). Loc.Cit. 